\title{
Sex-specific yield per recruit and spawning stock biomass per recruit for the swordfish, Xiphias gladius, in the waters around Taiwan
}

\author{
Chi-Lu Sun ${ }^{\mathrm{a}, *}$, Sheng-Ping Wang ${ }^{\mathrm{a}}$, Clay E. Porch ${ }^{\mathrm{b}}$, Su-Zan Yeh $^{\mathrm{a}}$ \\ a Institute of Oceanography, National Taiwan University, No. 1, Section 4, Roosevelt Road, Taipei 106, Taiwan \\ b Southeast Fisheries Science Center, National Marine Fisheries Service, NOAA, 75 Virginia Beach Drive, Miami, FL 33149, USA
}

Received 17 December 2003; received in revised form 9 June 2004; accepted 21 July 2004

\begin{abstract}
Sex-specific yield per recruit and spawning stock biomass per-recruit analyses were conducted to evaluate the population status of swordfish in the waters around Taiwan. Estimates of the total mortality rate, obtained from length composition data by catch-curve analysis, are on the order of 0.30 year $^{-1}$ for females and 0.35 year $^{-1}$ for males. Pauly's empirical method indicates natural mortality rates of 0.25 and 0.27 for females and males, implying that the current fishing mortality rate on either sex is less than 0.1 year $^{-1}$. This is well below the estimates for the target reference points $F_{40 \%}\left(0.12\right.$ year $\left.^{-1}\right)$ and $F_{0.1}\left(0.20\right.$ year $\left.^{-1}\right)$, suggesting the swordfish in the waters around Taiwan are not over-exploited. The spawning potential ratio associated with the current level of exploitation was estimated to be $65 \%$ of the pristine level. Isopleths of yield per recruit and spawning stock biomass per recruit generated with various mortality rates suggest that both the yield and spawning biomass per recruit could be increased by raising the age at first capture to a value greater than the age at the onset of sexual maturity.
\end{abstract}

(C) 2004 Elsevier B.V. All rights reserved.

Keywords: Swordfish; Yield per recruit; Spawning stock biomass per recruit; Reference point; Spawning potential rate

\section{Introduction}

The swordfish (Xiphias gladius Linnaeus, 1758) is a cosmopolitan species found in the tropical, subtropical and temperate waters of all oceans (Nakamura, 1985). In the waters around Taiwan, swordfish are

\footnotetext{
* Corresponding author. Tel.: +8862 2362 9842; fax: +886223629842.

E-mail address: chilu@ntu.edu.tw (C.-L. Sun).
}

taken mainly as a bycatch of tuna longline fisheries, although some are also taken by harpoon, gill net, or set net. During the last decade the landings have become substantial, fluctuating between 600 and $1700 \mathrm{mt}$. Nevertheless, little information has been collected on the historical fishing effort or length/age composition of the catch owing to the low price swordfish commands in comparison to tuna. Recently, however, several studies have estimated the growth and maturity of swordfish in the waters around Taiwan 
(Sun et al., 2002; Wang et al., 2003), making it possible to apply models of yield per recruit and spawning stock biomass per recruit. The objective of this study was to evaluate the population status of swordfish in the waters around Taiwan by comparing estimates of the current fishing mortality rate derived from samples of length with certain benchmark statistics derived from the per-recruit analyses (Butterworth et al., 1989; Punt, 1993; Govender, 1995; Griffiths, 1997).

\section{Materials and methods}

\subsection{Length and age composition of the catch}

Length composition data were obtained by measuring swordfish landed at the three major fish markets in Taiwan (Tungkang, Shinkang and Nanfangao; Fig. 1) during September 1997 to September 2001. On any given day, nearly all the swordfish landed at these markets were measured, weighed and identified to sex. The days of sampling were chosen at random from the total number of days the markets were operating; thus, the frequency distribution of length from the sample ought to resemble closely the frequency distribution for the entire Taiwanese catch.

Some of the length samples were accompanied by samples of the first anal fin, which Sun et al. (2002) used

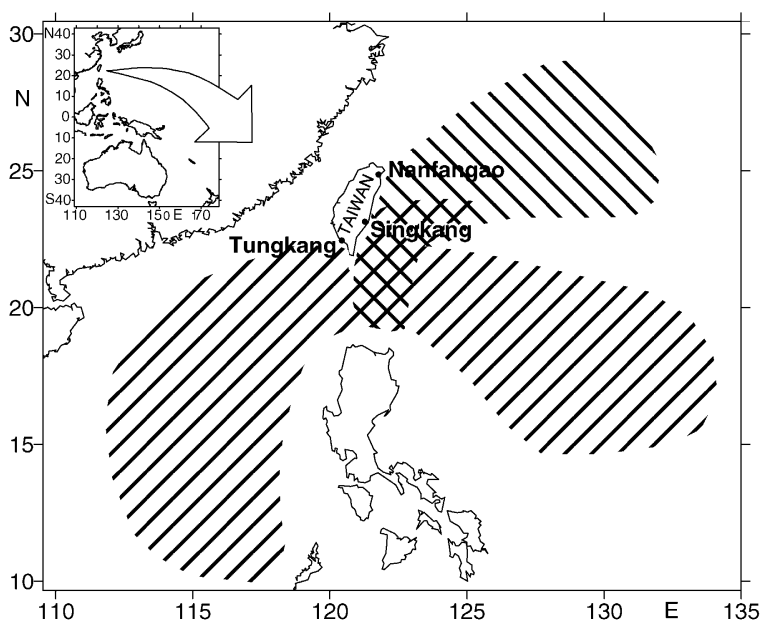

Fig. 1. Fishing ports in Taiwan where the length samples of swordfish were collected. Oblique line areas indicate the fishing grounds of longline fisheries based at Tungkang (left oblique), Nanfangao (right oblique) and Shinkang (intersection). to age the animals. This subsample of age-length pairs was used to construct sex-specific age-length keys, which in turn were used to convert the length frequency data into age-frequency. Inasmuch as older animals are difficult to age, animals longer than expected for age 9 were lumped together into plus-groups (see discussion in Unpublished, $1999^{1}$ ).

\subsection{Mortality rate estimation}

The total mortality rate $Z$ was estimated from the censored age-frequency distributions discussed above using two forms of catch-curve analyses. The first is a modification of the log-linear regression approach of Chapman and Robson (1960) that accommodates a plus-group. Maximum likelihood estimates for $Z$ (and an intercept parameter $\alpha$ ) are found by minimizing the negative log-likelihood expression below:

$$
\begin{gathered}
\left(\ln c_{t_{\mathrm{p}}}-\alpha-\ln \left(1-\mathrm{e}^{-Z\left(t_{\max }-t_{\mathrm{p}}\right)}\right)+Z\left(t_{\mathrm{p}}-t_{\mathrm{f}}\right)\right)^{2} \\
+\sum_{t=t_{\mathrm{f}}}^{t_{\mathrm{p}}-1}\left(\ln c_{t}-\alpha-\ln \left(1-\mathrm{e}^{-Z}\right)+Z\left(t-t_{\mathrm{f}}\right)\right)^{2}
\end{gathered}
$$

where $c_{t}$ is the frequency of age $t$ in the sample, $t_{\mathrm{f}}$ the first fully selected age class, $t_{\mathrm{p}}$ the first age in the plusgroup (here age 9), and $t_{\max }$ the maximum age. For comparison, a second set of estimates was obtained by taking the natural logarithm of the estimates of survival from the method of Robson and Chapman (1961), i.e.:

$Z=\ln \left(1+\frac{1-n_{\mathrm{p}} / n}{\bar{t}-t_{\mathrm{f}}}\right)$

where $n$ is the total number of observations, $n_{\mathrm{p}}$ the number of observations in the plus-group and $\bar{t}$ the average of the frequency histograms for age classes $\geq t_{\mathrm{f}}$. Both estimators were applied to data aggregated over the duration of the study period, rather than across cohorts, owing to the relatively small sample size.

The maximum lifespan $\left(t_{\max }\right)$ of swordfish is unknown. For this paper it was calculated using the

\footnotetext{
${ }^{1}$ Unpublished, 1999. Detailed report for swordfish. ICCAT SCRS Swordfish Stock Assessment Session, Madrid, Spain, September 27-October 4, 1999, 208 pp.
} 
Table 1

Biological parameters of swordfish in the waters around Taiwan estimated by Sun et al. (2002)

\begin{tabular}{lcc}
\hline Parameter & Male & Female \\
\hline$L_{\infty}$ & 207.52 & 267.44 \\
$K$ & 0.198 & 0.13 \\
$t_{0}$ & -1.955 & -2.302 \\
$a$ & $1.3528 \times 10^{-6}$ & \\
$b$ & 3.4297 & \\
\hline
\end{tabular}

empirical relationship of Taylor (1958):

$t_{\max }=t_{0}+\frac{2.996}{K}$

where $K$ and $t_{0}$ are the von Bertalanffy growth coefficient and intercept at length zero, respectively. Similarly, the natural mortality rate $(M)$ of swordfish is unknown and was calculated using Pauly's (1980) empirical regression on $K$, asymptotic length $\left(L_{\infty}\right)$ and temperature. The von Bertalanffy parameter estimates used are summarized in Table 1. The value for temperature was the annual mean sea surface temperature in the vicinity of Taiwan (about $25^{\circ} \mathrm{C}$, IGOSS, 2002).

\subsection{Per-recruit analyses}

The model used to estimate the potential yield per recruit (Y/R) of swordfish in the waters around Taiwan was based on the method of Thompson and Bell (1934):

$\frac{\mathrm{Y}}{\mathrm{R}}=\sum_{t=t_{\mathrm{c}}}^{t_{\max }}\left(\bar{W}_{t} \cdot \frac{F_{t}}{Z_{t}} \cdot\left(1-\mathrm{e}^{\left(-F_{t}+M\right)}\right) \cdot \mathrm{e}^{-\sum_{i=0}^{t-1}\left(F_{i}+M\right)}\right)$

where $\bar{W}_{t}$ is the mean weight of fish at age $t$ and $F_{t}$ the fishing mortality of fish at age $t$. Mean weight at age was computed as a power function of midyear lower jaw fork length $\left(L_{t}\right)$ :

$W_{t}=a \cdot L_{t}^{\mathrm{b}}$

and midyear lower jaw fork length was computed as a von Bertalanffy function of age

$L_{t}=L_{\infty}\left(1-\mathrm{e}^{-K\left(t+0.5-t_{0}\right)}\right)$

(see Table 1).
The fishing mortality rate at age is expressed as the product of age-independent fishing mortality $F$ and age-dependent selectivity $S_{t}$ :

$F_{t}=F S_{t}$

No information on the selectivity at age is available for swordfish captured in the waters around Taiwan. For lack of a better alternative, we assume it is knife-edged at various ages at first capture $\left(t_{\mathrm{c}}\right)$.

The equation for spawning stock biomass per recruit $(\mathrm{SSB} / \mathrm{R})$ is

$\frac{\mathrm{SSB}}{\mathrm{R}}=\sum_{t_{\mathrm{m}}}^{t_{\max }}\left(\mathrm{fr}_{t} \cdot W_{t} \cdot \mathrm{e}^{-\sum_{i=t_{\mathrm{r}}}^{t-1}\left(F_{i}+M\right)}\right)$

Here $W_{t}$ is the expected weight at age $t$ from von Bertalanffy curve for female swordfish and fr the fraction of female swordfish that are mature. In this case fr is represented by a logistic equation fitted to maturity data collected from swordfish caught in the waters around Taiwan (Sun et al., 2002; Wang et al., 2003).

$\mathrm{fr}_{t}=\frac{1}{1+\mathrm{e}^{-1.899(t-4.693)}}$

\subsection{Reference points}

The following reference points were used to determine the status of the stock: $F_{0.1}$, the fishing mortality rate corresponding to the point where the slope of the yield per recruit curve equals $10 \%$ of the slope at the origin (Gulland and Boerema, 1973); $F_{\max }, F$ that produces the maximum yield per recruit; and $F_{\mathrm{SPR}}$, the $F$ that produces a given spawning potential ratio. The spawning potential ratio (SPR) is the SSB/R at given fishing mortality divided by the SSB/R without fishing (Gabriel et al., 1989; Goodyear, 1993; Katsukawa et al., 1999; Watanabe et al., 2000; Sun et al., 2002)

$\mathrm{SPR}=\frac{\mathrm{SSB} / \mathrm{R}}{(\mathrm{SSB} / \mathrm{R})_{F=0}}$

\section{Results}

Length data were obtained for 968 swordfish (574 females and 394 males) and age data for 629 of these (336 females and 293 males). The range of lower 


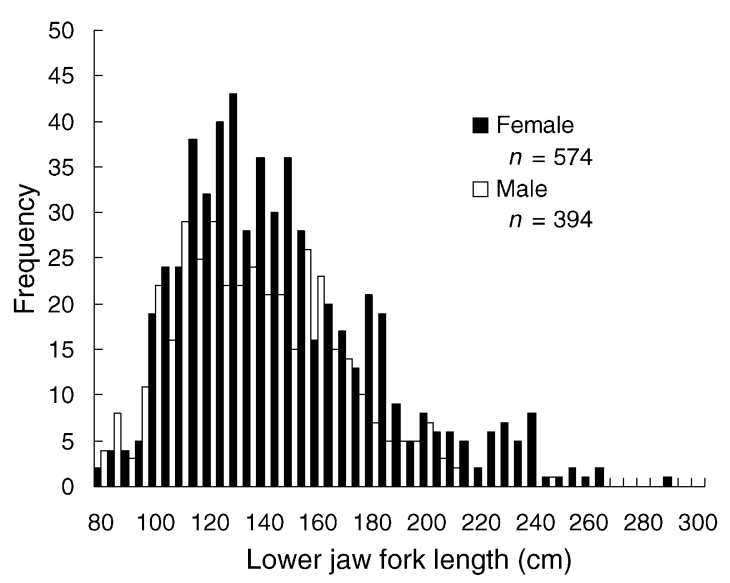

Fig. 2. The length-frequency distributions ( $5 \mathrm{~cm}$ intervals $)$ of swordfish in the waters around Taiwan.

jaw fork length was $75.5-290 \mathrm{~cm}$ for females and $78-206 \mathrm{~cm}$ for males (Fig. 2). The corresponding agefrequency distributions (Fig. 3) indicate that most of the swordfish caught in the waters around Taiwan were
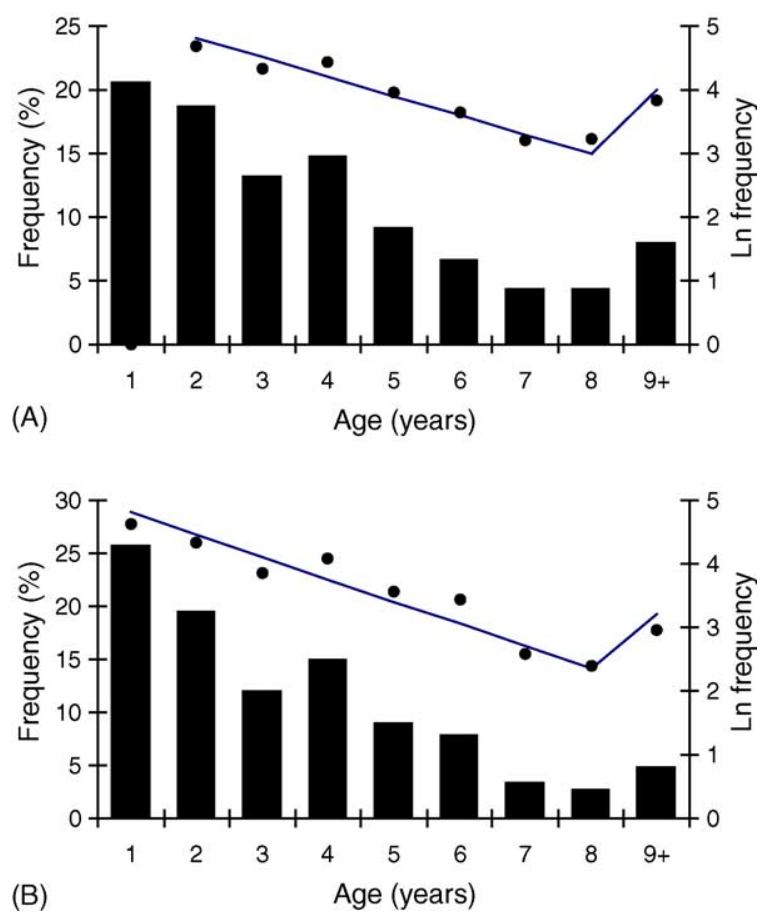

Fig. 3. The age-frequency distributions (bars) and catch curves (circles) of female (A) and male (B) swordfish in the waters around Taiwan. under the age of $50 \%$ maturity, being between 1 and 4 years old, with a peak at age 1 . In the case of females, the frequencies of ages 1 and 2 are similar suggesting that age 1 may not yet be fully selected. Accordingly, the age of full recruitment $t_{\mathrm{c}}$ was set to age 1 for males and age 2 for females. The empirical estimates of $t_{\max }$ were 13 years for males and 21 years for females. No fish were observed older than these ages in our samples.

The estimates of $Z$ from the censored regression analyses, assuming the above values for $t_{\mathrm{c}}$ and $t_{\max }$, were 0.30 year $^{-1}$ for females and 0.35 year $^{-1}$ for males. The Chapman-Robson estimates were similar ( 0.30 year $^{-1}$ for females and 0.33 for males). There were no consistent trends in the residual patterns that would suggest gross violations of the steady state assumption underlying the catch-curve analyses (constant recruitment and mortality rates). Accordingly, we believe the estimates to be a reasonable indication of the average mortality rate during the study period.

The estimates of $F_{\text {current }}, F_{0.1}, F_{\max }$ and Y/R (assuming knife-edge selection at the peak ages) under various values of $M$ are summarized in Table 2 and Fig. 4. The values of $M$ estimated by Pauly's empirical equation were 0.25 year $^{-1}$ for females and 0.27 year $^{-1}$ for males. Using these as our base, the corresponding estimates for $F_{\text {current }}$ are 0.05 year $^{-1}$ for females and 0.08 year $^{-1}$ for males, which are substantially lower than the corresponding reference points $F_{\max }$ ( 0.45 year $^{-1}$ for females and 0.43 year $^{-1}$ for males) and $F_{0.1}\left(0.20\right.$ year $^{-1}$ for both females and males $)$. Consequently, the estimates of $\mathrm{Y} / \mathrm{R}_{\text {current }}(6.23 \mathrm{~kg}$ for females and $5.89 \mathrm{~kg}$ for males) were lower than $\mathrm{Y} / \mathrm{R}_{\max }$ (13.09 kg for females and $9.48 \mathrm{~kg}$ for males) and $\mathrm{Y} / \mathrm{R}_{0.1}$ (11.95 kg for females and $8.51 \mathrm{~kg}$ for males).

Table 2

Estimates of current fishing mortality $\left(F_{\text {current }}\right)$ and Y/R $(\mathrm{kg})$ reference points for female and male swordfish taken in the waters around Taiwan

\begin{tabular}{|c|c|c|c|c|c|c|}
\hline$M$ & $F_{\text {current }}$ & $F_{0.1}$ & $F_{\max }$ & $\mathrm{Y} / \mathrm{R}_{\text {current }}$ & $\mathrm{Y} / \mathrm{R}_{0.1}$ & $\mathrm{Y} / \mathrm{R}_{\max }$ \\
\hline \multicolumn{7}{|c|}{ Female } \\
\hline 0.20 & 0.10 & 0.15 & 0.30 & 13.38 & 15.23 & 16.59 \\
\hline 0.25 & 0.05 & 0.20 & 0.45 & 6.23 & 11.95 & 13.09 \\
\hline 0.30 & 0.003 & 0.25 & 0.71 & 0.32 & 9.68 & 10.83 \\
\hline \multicolumn{7}{|l|}{ Male } \\
\hline 0.20 & 0.16 & 0.20 & 0.30 & 11.23 & 11.88 & 12.35 \\
\hline 0.27 & 0.08 & 0.20 & 0.43 & 5.89 & 8.51 & 9.45 \\
\hline 0.30 & 0.06 & 0.24 & 0.50 & 3.81 & 7.89 & 8.62 \\
\hline
\end{tabular}



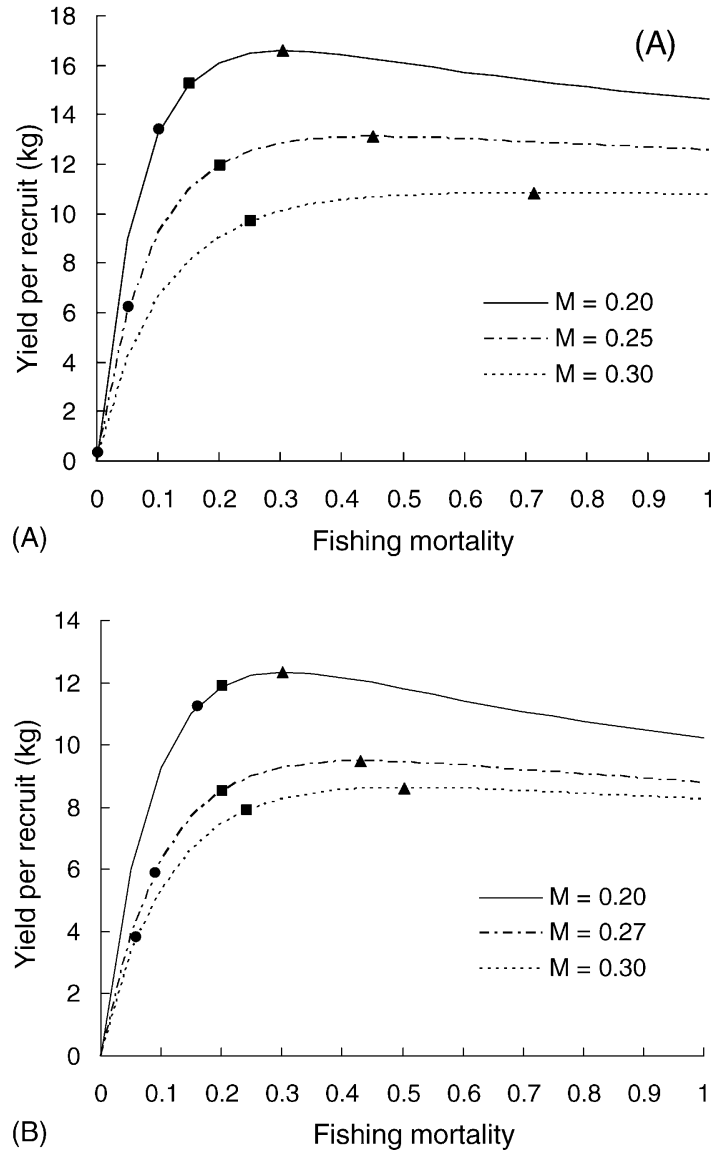

Fig. 4. Yield per recruit against fishing mortality for female (A) and male (B) swordfish in the waters around Taiwan (circles are current levels, squares are $F_{0.1}$ levels, and triangles are $F_{\max }$ levels).

The effect of varying the age at first capture on Y/R is demonstrated for various values of $M(0.20,0.25$, 0.30 year $^{-1}$ for females and $0.20,0.27,0.30$ year $^{-1}$ for males) in Fig. 5. The Y/R increased rapidly at low levels of $F$ for most of the range of $t_{\mathrm{c}}$. The values of $t_{\mathrm{c}}$ that maximized the yield per recruit decreased with the magnitude of $M$ and increased with the level of $F$, but typically ranged between 2 and 5 years for females and 2-3 years for males.

The estimates of $F_{25}, F_{40 \%}$, SPR and Y/R (assuming knife-edge selection at the peak ages) under the various values of $M$ are summarized in Table 3 and Fig. 6. Our 'base' estimate of $F_{\text {current }}$ for females $\left(0.05\right.$ year $\left.^{-1}\right)$ was lower than the corresponding reference points $F_{25 \%}\left(0.19\right.$ year $\left.^{-1}\right)$ and $F_{40 \%}\left(0.12\right.$ year $\left.^{-1}\right)$ and the current level of SPR was estimated to be about $65 \%$ of the unfished level. Under the low value of $M$ $\left(0.2\right.$ year $\left.^{-1}\right)$, the estimate of $F_{\text {current }}$ for females was about the same as $F_{40 \%}\left(0.10\right.$ year $\left.^{-1}\right)$. Increasing the age of first capture to between 5 and 7 years of age would ensure that the SPR is maintained between values of $25 \%$ and $40 \%$ at almost any level of fishing (Fig. 7) with relatively little impact on Y/R.

\section{Discussion}

Reference points such as $F_{0.1}, F_{\max }, F_{25 \%}$ and $F_{40 \%}$ have often been used to develop fishery management strategies. Several authors have advocated designating $F_{0.1}$ or $F_{40 \%}$ as target reference points and $F_{25 \%}$ as a threshold reference point in order to obtain near optimal yields while ensuring against stock collapse (Gulland and Boerema, 1973; Deriso, 1987; Sissenwine and Shepherd, 1987; Quinn et al., 1990; Hildén, 1993; Leaman, 1993; Mace and Sissenwine, 1993; Rivard and Maguire, 1993; Thompson, 1993; Mace, 1994; Chen, 1997; Griffiths, 1997; Kirchner, 2001). The results of the base Y/R and SPR analyses in this study suggest that the current fishing mortality rates on swordfish in the waters of Taiwan are not only lower than the threshold reference point $F_{25 \%}$, but lower than the target reference points $F_{0.1}$ and $F_{40 \%}$ as well. This indicates that the stock of swordfish in the waters around Taiwan is not being overfished and may even be somewhat underexploited.

The values used here for our base estimates of natural mortality $\left(0.25\right.$ and 0.27 year $^{-1}$ for females and males) are somewhat greater than the value of 0.22 year $^{-1}$ used in previous studies (Boggs, 1989; Joseph et al., 1994; Punt et al., 2001). The value of 0.22 year $^{-1}$ was also obtained by Pauly's (1980) method, but using the unisex growth parameters of Yabe et al. (1959). As it turns out, our conclusions that the stock is not over-fished still holds with a value of $M$ as low as 0.2 year $^{-1}$, the estimates of current fishing mortality rate remaining at or below all the corresponding reference points.

Our base results suggest that the yield per recruit could be increased by as much as $168 \%$ for females and $107 \%$ for males simply by increasing the fishing mortality rate to the level corresponding to $F_{40 \%}$. Additional gains in $\mathrm{Y} / \mathrm{R}$ might be achieved by further 
(A) Female

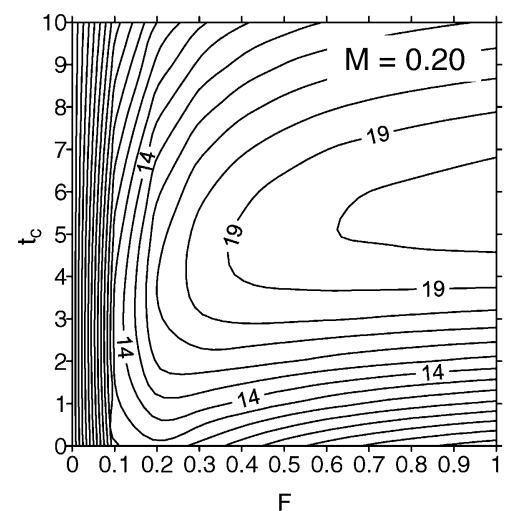

$\mathrm{F}$

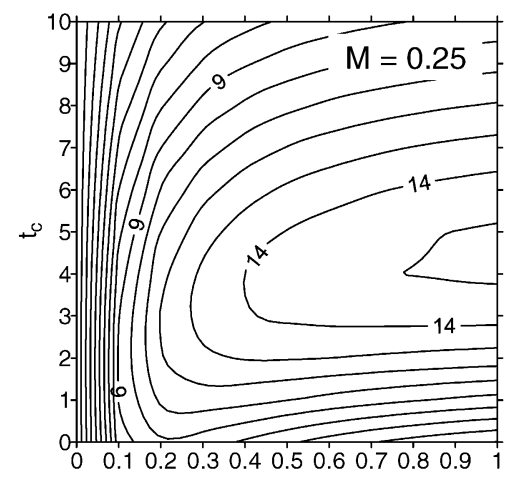

$\mathrm{F}$

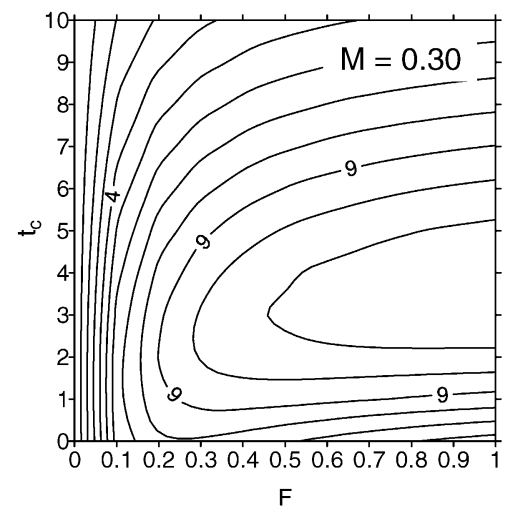

(B) Male

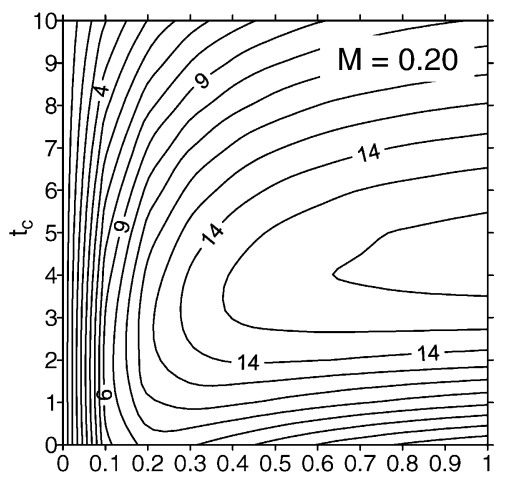

$\mathrm{F}$

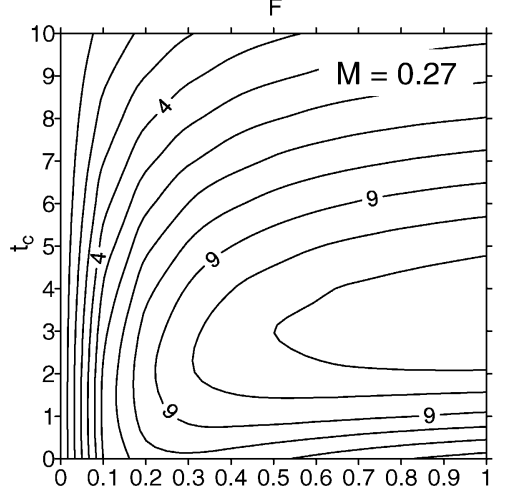

$\mathrm{F}$

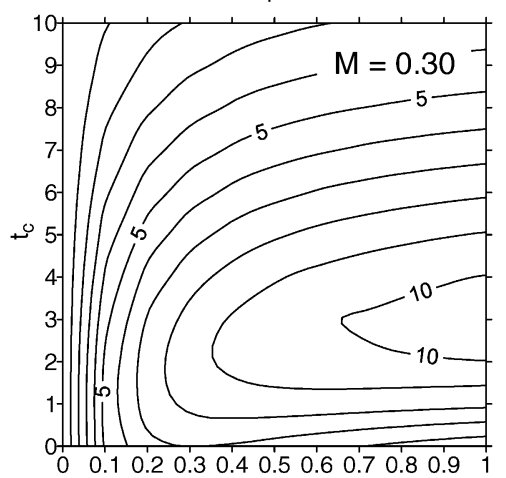

$\mathrm{F}$

Fig. 5. Isopleths of yield per recruit against fishing mortality $(F)$ and age at first capture $\left(t_{\mathrm{c}}\right)$ for female (A) and male (B) swordfish in the waters around Taiwan.

Table 3

Estimates of current fishing mortality $\left(F_{\text {current }}\right)$ and SPR reference points for female swordfish taken in the waters around Taiwan

\begin{tabular}{lllllrrr}
\hline$M$ & $\mathrm{SPR}_{\text {current }}$ & $F_{\text {current }}$ & $F_{25 \%}$ & $F_{40 \%}$ & $\mathrm{Y} / \mathrm{R}_{\text {current }}$ & $\mathrm{Y} / \mathrm{R}_{25 \%}$ & $\mathrm{Y} / \mathrm{R}_{40 \%}$ \\
\hline 0.20 & 41.43 & 0.10 & 0.17 & 0.1 & 13.38 & 15.68 & 13.59 \\
0.25 & 64.85 & 0.05 & 0.19 & 0.12 & 6.23 & 11.75 & 9.93 \\
0.30 & 97.68 & 0.003 & 0.20 & 0.13 & 0.32 & 9.11 & 7.53 \\
\hline
\end{tabular}




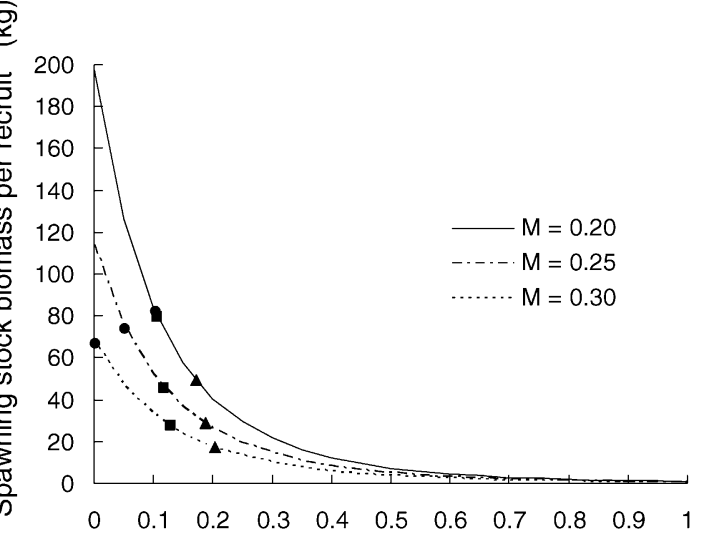

A)

Fishing mortality

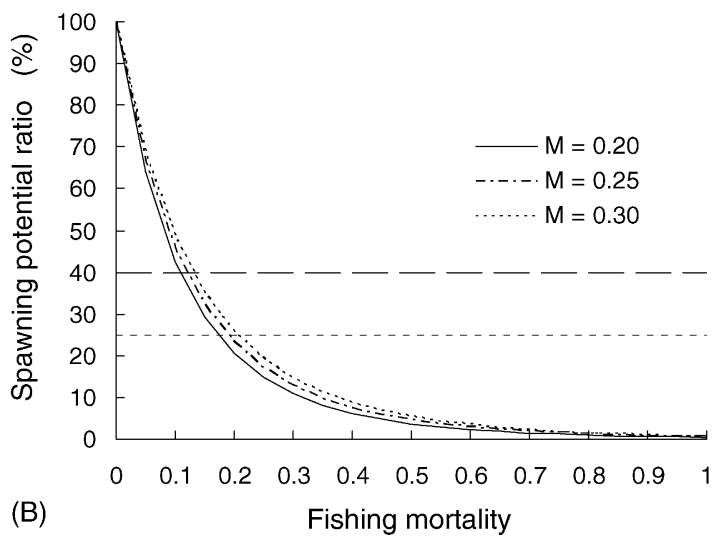

Fig. 6. Spawning stock biomass per recruit (A) and spawning potential ratio (B) against fishing mortality for female swordfish in the waters around Taiwan (circles are current levels, squares are $F_{40 \%}$ levels, and triangles are $F_{25 \%}$ levels).

increases to $F_{0.1}$, but SPR would decrease to under $25 \%$ of the pristine condition. If instead $M$ is closer to 0.2 year $^{-1}$, then the fishery is already close to being fully exploited and increases in $F$ are unlikely to substantially increase the $\mathrm{Y} / \mathrm{R}$.

There are no management measures for swordfish in the waters around Taiwan at the present time. The swordfish caught in Taiwanese waters are taken mainly as a bycatch of the tuna longline fishery. This makes it difficult to control the effective fishing effort for swordfish directly. However, it is possible to control the age at first capture indirectly through the use of minimum size limits. In that case, the isopleths of Y/R suggest that increasing $t_{\mathrm{c}}$ to an age between 3 and 5 years old

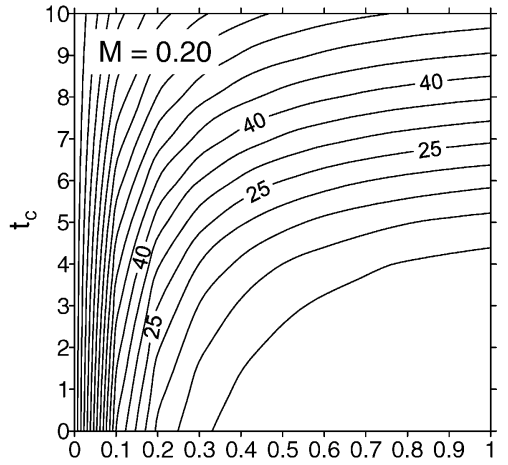

$\mathrm{F}$

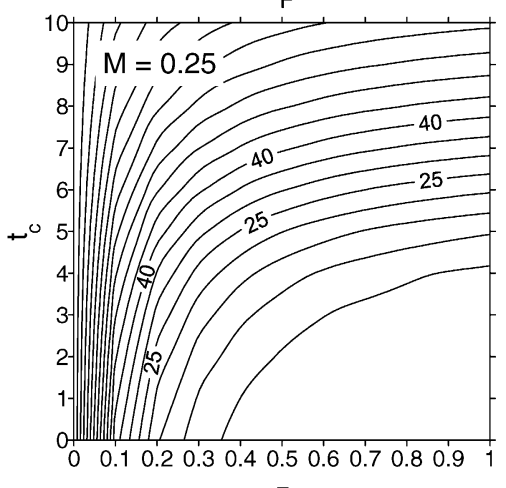

$\mathrm{F}$

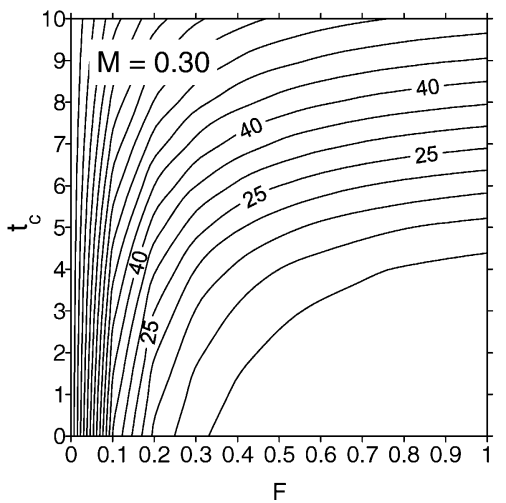

Fig. 7. Isopleths of spawning potential ratio against fishing mortality $(F)$ and age at first capture $\left(t_{\mathrm{c}}\right)$ for female swordfish in the waters around Taiwan.

would likely result in modest gains in terms of $\mathrm{Y} / \mathrm{R}$ (on the order of $10 \%$ ) while also hedging against recruitment overfishing. For example, the target level of $40 \%$ SPR could be achieved at even very large values of $F$ if $t_{\mathrm{c}}$ for female swordfish was larger than 5 years (the age at sexual maturity). Of course the efficacy of increasing $t_{\mathrm{c}}$ would be mitigated by any substantial release mor- 
tality. At present little is known about the mortality rates of fish released from longline vessels operating off Taiwan and further study is needed before we can confidently recommend increasing $t_{\mathrm{c}}$ as a measure to prevent overfishing.

There is a possibility that the low $F$ estimates may be an artifact of an influx of fish from outside the study area. Such a bias could occur if the probability that a fish will move from distant waters to within range of the local Taiwanese fleet is substantial and increases with the age of the animal. While recent analyses of mitochondrial DNA do suggest that the swordfish in the waters around Taiwan are part of a larger population in the northwestern Pacific Ocean (see Reeb et al., 2000), there is no evidence to suggest that swordfish become increasingly likely to migrate to Taiwan with age.

\section{Acknowledgements}

We thank the anonymous referees for their comments. This study was partially financially supported by the Fisheries Agency, Council of Agriculture, Taiwan, through the grant 90-AS-1.4.5-FA-F1(4) to ChiLu Sun.

\section{References}

Boggs, C.H., 1989. Vital rate statistics for billfish stock assessment. In: Stroud, R.H. (Ed.), Proceedings of the Second International Billfish Symposium on Planning the Future of Billfishes. Part 1. Fishery and Stock Synopses, Data Needs and Management. Kailua-Kona, Hawaii, August 1-5. National Coalition for Marine Conservation, Inc., Savannah, GA, pp. 225-233.

Butterworth, D.S., Punt, A.E., Borches, D.L., Pugh, J.G., Hughes, G.S., 1989. A manual of mathematical techniques for linefish assessment (incorporating report of the SANCOR Marine Linefish Programme's Workshop on Population Dynamics, February 4-6, 1987, Cape Town). S. Afr. Natl. Sci. Prog. Rep. 160, 89.

Chapman, D.G., Robson, D.S., 1960. The analysis of a catch curve. Biometrics 16, 354-368.

Chen, Y., 1997. A comparison study of age- and length-structured yield-per-recruit models. Aquat. Living Resour. 10, 271-280.

Deriso, R.B., 1987. Optimal $F_{0.1}$ criteria and their relationship to maximum sustainable yield. Can. J. Fish. Aquat. Sci. 44, 339-348.

Gabriel, W.L., Sissenwine, M.P., Overholtz, W.J., 1989. Analysis of spawning stock biomass per recruit: an example for Georges Bank Haddock. N. Am. J. Fish. Manage. 9, 383-391.

Goodyear, C.P., 1993. Spawning stock biomass per recruit in fisheries management: foundation and current use. Can. Spec. Publ. Fish. Aquat. Sci. 120, 67-81.
Govender, A., 1995. Mortality and biological reference points for the king mackerel (Scomberomorus commerson) fishery off Natal, South Africa (based on a per-recruit assessment). Fish. Res. 23, 195-208.

Griffiths, M.H., 1997. The application of per-recruit models to Argyrosomus inodorus, an important South African sciaenid fish. Fish. Res. 30, 103-115.

Gulland, J.A., Boerema, L.K., 1973. Scientific advice on catch levels. Fish. Bull. 71, 325-335.

Hildén, M., 1993. Reference points for fisheries management: the ICES experience. Can. Spec. Publ. Fish. Aquat. Sci. 120, 59-66.

IGOSS, 2002. Integrated Global Ocean Services System Products Bulletin. http://ingrid. Ideo.columbia.edu/SOURCES/IGOSS.

Joseph, J., Bayliff, W.H., Hinton, M.G., 1994. A review of information on the biology, fisheries, marketing and utilization, fishing regulations, and stock assessment of swordfish, Xiphias gladius, in the Pacific Ocean. Inter-American Tropical Tuna Commission, La Jolla, CA.

Katsukawa, T., Lee, Y., Matsumiya, Y., 1999. Spawning per recruit analysis for female snow crab Chionoecetes opilio in the Sea off Kyoto prefecture. Nippon Suisan Gakk 65, 288-293.

Kirchner, C.H., 2001. Fisheries regulations based on yield-per-recruit analysis for the linefish silver kob Argyrosomus inodorus in Namibian waters. Fish. Res. 52, 155-167.

Leaman, B.M., 1993. Reference points for fisheries management: the western Canadian experience. Can. Spec. Publ. Fish. Aquat. Sci. 120, 15-30.

Mace, P.M., 1994. Relationships between common biological reference points used as thresholds and target of fisheries management strategies. Can. J. Fish. Aquat. Sci. 51, 110-122.

Mace, P.M., Sissenwine, M.P., 1993. How much spawning per recruit is enough? Can. Spec. Publ. Fish. Aquat. Sci. 120, 101118.

Nakamura, I., 1985. FAO species catalogue, vol. 5. Billfishes of the world. An annotated and illustrated catalogue of marlins, sailfishes, spearfishes and swordfishes known to date. FAO Fish Synop. 125 (5).

Pauly, D., 1980. On the interrelationships between natural morality, growth parameters and mean environmental temperatures in 175 fish stocks. J. Cons. Int. Mer. 39, 175-192.

Punt, A.E., 1993. The use of spawner-biomass-per-recruit in the management of linefisheries. In: Beckley, L.E., van der Elst, R.P. (Eds.), Proceedings of the Second South African Marine Linefish Symposium on Fish, Fishers and Fisheries, Oceanographic Research Institute, Special Publication, No. 2, pp. 80-89.

Punt, A.E., Campbell, R.A., Smith, A.D.M., 2001. Evaluating empirical indicators and reference points for fisheries management: application to the broadbill swordfish fishery off eastern Australia. Mar. Freshw. Res. 52, 819-832.

Quinn II, T.J., Fagen, R., Zheng, J., 1990. Threshold management policies for exploited population. Can. J. Fish. Aquat. Sci. 47, 2016-2029.

Reeb, C.A., Arcangeli, L., Block, B.A., 2000. Structure and migration corridors in Pacific populations of the swordfish Xiphias gladius, as inferred through analyses of mitochondrial DNA. Mar. Biol. 136, 1123-1131. 
Rivard, D., Maguire, J.-J., 1993. Reference points for fisheries management: the eastern Canadian experience. Can. Spec. Publ. Fish. Aquat. Sci. 120, 31-58.

Robson, D.S., Chapman, D.G., 1961. Catch curves and mortality rates. Trans. Am. Fish. Soc. 90, 181-189.

Sissenwine, M.P., Shepherd, J.G., 1987. An alternative perspective on recruitment overfishing and biological reference points. Can. J. Fish. Aquat. Sci. 44, 913-918.

Sun, C.L., Wang, S.P., Yeh, S.Z., 2002. Age and growth of swordfish (Xiphias gladius L.) in the waters around Taiwan determined from anal-fin rays. Fish. Bull. 100, 822-835.

Taylor, C.C., 1958. Cod growth and temperature. J. Cons. Int. Explor. Mer. 23, 366-370.

Thompson, G.G., 1993. A proposal for a threshold stock size and maximum fishing mortality rate. Can. Spec. Publ. Fish. Aquat. Sci. 120, 303-320.
Thompson, W.F., Bell, F.H., 1934. Biological statistics of the Pacific halibut fishery. 2. Effect of changes in intensity upon total yield and yield per unit of gear. Rep. Int. Fish. (Pacific Halibut) Comm. 8,49 .

Wang, S.P., Sun, C.L., Yeh, S.Z., 2003. Sex ratios and sexual maturity of swordfish (Xiphias gladius L.) in the waters of Taiwan. Zool. Stud. 42, 529-539.

Watanabe, K., Hosho, T., Saiura, K., Okazake, T., Matumiya, Y., 2000. Fisheries management by spawning per recruit analysis for the threeline grunt Parapristipoma trilineatum around Mugi-oshima Island on the coastal area of Tokushima prefecture. Nippon Suisan Gakk 66, 690696.

Yabe, H., Ueyanagi, S., Kikawa, S., Watanabe, H., 1959. Study on the life-history of the swordfish, Xiphias gladius Linneaus. Rep. Nankai Reg. Fish. Res. Lab. 10, 107-150. 